\title{
Studies of Immunomodulating Actions of RNA/ Nucleotides. RNA/Nucleotides Enhance In Vitro Immunoglobulin Production by Human Peripheral Blood Mononuclear Cells in Response to T-Dependent Stimuli
}

\author{
HARUMI JYONOUCHI, LEI ZHANG, AND YOSHIFUMI TOMITA \\ Department of Pediatrics, University of Minnesota, Minneapolis, Minnesota, 55455 [H.J., L.Z.]; and Department \\ of Animal Nutrition, Miyazaki University, Miyazaki, Japan [Y.T.]
}

\begin{abstract}
We have shown previously that yeast RNA preparations enhance in vitro antibody and Ig production to T-dependent antigens in normal B6 mice. In this study, Ig production by human peripheral blood mononuclear cells from adult volunteers was examined under RNA and mononucleotide-supplemented culture conditions. RNA significantly enhanced IgM and IgG production in a dose-dependent manner to pokeweed mitogen, T-dependent stimuli, and keyhole limpet hemocyanin modified with trinitrophenol, T-dependent antigens. IgM and IgG production in response to $T$-independent stimuli were not significantly altered by RNA and mononucleotides. IgA production appeared not to be influenced by RNA and mononucleotides irrespective of the stimuli provided. Interestingly, spontaneous IgM production also appeared to be enhanced by RNA. When RNA was degraded, oxidized, or decomposed of pyrimidine bases, this enhancing action of RNA on Ig production was considerably reduced. RNA was most effective when present from $d 0$ of the culture. Its enhancing action was lost when it was added at $\mathrm{d} 3$ of the culture or later, when $T$ cells were depleted, or when direct interactions between $T$ cells and non- $T$ cells were not permitted in the culture. Thus, RNA may enhance IgM and IgG production by human peripheral blood mononuclear cells to $\mathbf{T}$-dependent stimuli partly by influencing the process of direct cellular interactions between $T$ and non$T$ cells in the early stage of B-cell activation. (Pediatr Res 33: 458-465, 1993)
\end{abstract}

\section{Abbreviations}

HPBMNC, human peripheral blood mononuclear cell GI, gastrointestinal

PWM, pokeweed mitogen

SAC, Staphylococcus aureus Cowan I

SRBC, sheep red blood cell

TD-Ag, T-dependent antigen

TI-Ag, T-independent antigen

TNP-KLH, keyhole limpet hemocyanin modified with trinitrophenol

TNP-LPS, lipopolysaccharide modified with trinitrophenol

Received August 13, 1992; accepted December 29, 1992.

Correspondence and reprint requests: Harumi Jyonouchi, M.D., Division of Immunology, Department of Pediatrics, University of Minnesota, Box 610, UMHC, 516 Delaware St. S.E., Minneapolis, MN 55455.

Supported by NIH Grant AI25063, a grant from Minnesota Medical Foundation, a grant from Graduate School, University of Minnesota, and a grant from Viking's Children's Foundation (H.J.).
TNP, trinitrophenol

Ab, antibody

TNP-Ficoll, Ficoll modified with TNP

Exogenous nucleotides provided through regular diet are thought to have no significant nutritional impact in well-nourished individuals, because most nucleotides appeared to be provided through de novo synthesis in the body $(1,2)$. However, certain organs, such as the intestine, have a limited capacity for de novo synthesis of nucleotides, relying on an active salvage pathway of dietary nucleosides and bases to maintain nucleotide pools (3). Therefore, it would be quite possible that dietary nucleotides are used more during times of increased need for nucleotides, such as when the body is recovering from significant tissue injury or during rapid growth. Human breast milk is known to contain significant amounts of nucleotides, likely coinciding with the increased need of dietary nucleotides at the time of rapid growth in early infancy (3). In animals, dietary nucleotides appear to enhance crypt cell proliferation in GI tract, resulting in augmented digestive capacity, and may also have some benefits in the lipid metabolism (3-6). Nevertheless, no disease associated with deficiency in dietary nucleotides has been documented in normal infants. This fact may undermine the significance of any role that dietary nucleotides play in normal growth and development of infants.

The impact of dietary nucleotides on the immune system is also not clearly understood. However, lymphoid organs are relatively limited in the capacity of de novo synthesis for nucleotides, just as GI tract and exogenous nucleotides may play crucial roles in certain circumstances. For example, in mice fed nucleotide-free diets, a significant decrease in T-cell functions has been demonstrated (7-9). These mice were less resistant to sepsis caused by Staphylococcus aureus and Candida albicans $(10,11)$. In patients on total parenteral nutrition in which nucleotides were not supplemented, delayed allograft rejection has also been reported (7).

We have previously explored the immunomodulating actions of polynucleotides on murine lymphocytes in the RNA-supplemented culture and found striking enhancement of in vitro $\mathrm{Ab} /$ Ig production against TD-Ag in this condition (12-14). However, there was no further augmentation of polyclonal B-cell activation (13). To exert its enhancing actions at optimal levels, RNA must be present from the initial period of antigen priming and seem to exert their actions through $\mathrm{T}$ helper cells either directly or indirectly $(12-14)$. 
Based on these results, this study was undertaken to address the actions of RNA/mononucleotides on human lymphocytes in vitro, and, for that purpose, we initially examined Ig production by HPBMNC potentiated by various stimuli in the RNA/mononucleotide-supplemented culture conditions.

\section{MATERIALS AND METHODS}

Experimental Design. Experiments were conducted to study the following subjects.

In vitro Ig production by HPBMNC in response to T-dependent and T-independent stimuli in RNA-supplemented culture. This study was designed based on the fact that RNA preferentially enhance in vitro $\mathrm{Ab} / \mathrm{Ig}$ production to $\mathrm{TD}-\mathrm{Ag}$ in $\mathrm{B} 6$ mice (12-14).

Effects of chemically modified/degraded RNA on in vitro Ig production by $H P B M N C$. This study was designed to examine whether any immunomodulating actions of RNA preparations observed on Ig production by HPBMNC are truly attributable to RNA or their degraded products.

Effects of mononucleotide mixtures on in vitro Ig production by HPBMNC. This experiment was planned because we observed that the enhancing actions of RNA on in vitro $\mathrm{Ab}$ production were partially reproduced by certain mononucleotides in B6 mice, and human breast milk contains a fair number of mononucleotides $(3,12)$.

Mechanisms of actions of RNA on in vitro Ig production by $H P B M N C$. In $\mathrm{B} 6$ mice, RNA appeared to enhance in vitro $\mathrm{Ab} /$ Ig production against $\mathrm{TD}-\mathrm{Ag}$ by exerting their actions at the initial stage of antigen priming in a dose-dependent manner (1214). Therefore, the study was designed to examine the Ig production by HPBMNC in response to various doses of RNA and the time course of the supplementation of RNA to the culture. The effects of depletion of T cells or the inhibition of direct interactions between $\mathrm{T}$ and other lineage cells were also studied.

In each experiment, HPBMNC were obtained from healthy adult volunteers. The methodology used in this study was as follows:

Preparation of Cell Suspensions. HPBMNC were separated by Ficoll-Hypaque gradient and washed with $\mathrm{PBS}, \mathrm{pH} 7.4$, three times. T cells were depleted from HPBMNC by E-rosetting with neuraminidase-treated SRBC after Ficoll-Hypaque gradient (15). In some experiments, cell suspensions enriched for $T$ cells by Erosetting were also used. In these cases, T-cell-enriched cell suspensions were placed in ice-cold $\mathrm{NH}_{4} \mathrm{Cl}(0.17 \mathrm{M})$ for $5 \mathrm{~min}$ to lyse SRBC and washed three times in PBS. More than 95\% of cells of T-cell-enriched cell suspensions expressed pan T-cell markers (CD3 and CD5). These cells were then cocultured with T-depleted cells in a diffusion chamber that does not permit direct interactions between $T$ cells and other lineage cells (Transwell, Costar, Cambridge, MA).

Ig Production Assay. Prepared HPBMNC were incubated for 7 to $14 \mathrm{~d}$ in RPMI 1640 supplemented with $2 \%$ FCS (Hyclone, Logan, UT), penicillin and streptomycin, $N$-2-hydroxyethylpiperazine- $N^{\prime}$-2-ethanesulfonic acid, glutamine, and 2-mercaptoethanol $\left(10^{-5} \mathrm{M}\right)\left(10^{9}\right.$ cells/L) in $5-\mathrm{mL}$ disposable plastic tubes (Costar). Stimuli used to potentiate Ig production included SAC $(0.05 \mathrm{~g} / \mathrm{L})$ as a $\mathrm{T}$-independent stimulant and PWM $(1: 1000)$ as a T-dependent stimulant. SRBC $(0.05 \%)$ and TNP-KLH $(10$ $\mathrm{mg} / \mathrm{L})$ were used as TD-Ag. TNP-LPS $(2 \mathrm{mg} / \mathrm{L})$ and TNP-Ficoll $(10 \mathrm{mg} / \mathrm{L})$ were used as $\mathrm{TI}-\mathrm{Ag}(16)$. Concentrations of stimuli used were the same as those used to induce optimal responses in previous studies in both humans and animals (12 and unpublished manuscript). After the incubation of cells in a $5 \% \mathrm{CO}_{2}$ incubator for 7 to $14 \mathrm{~d}$ at $37^{\circ} \mathrm{C}$, supernatants were harvested, and $0.02 \% \mathrm{NaN}_{3}$ was added. The cells were kept at $4^{\circ} \mathrm{C}$ until the time of use. $\operatorname{IgG}, \operatorname{IgM}$, and IgA levels in the harvested supernatant were measured by standard solid-phase ELISA assay (17). Plates for ELISA assay (F96 Maxisorp, Nunc, Naperville, IL) were coated with anti-human $\lg (10 \mathrm{mg} / \mathrm{L})$ overnight at $4^{\circ} \mathrm{C}$ in $0.1 \mathrm{~N}$
$\mathrm{NaHCO}_{3}$ coating buffer, pH 9.6, with $0.02 \% \mathrm{NaN}_{3}$. After washing the plate with rinse buffer (PBS, $\mathrm{pH} 7.4,0.05 \%$ Tween 20), samples were diluted with dilution buffer $(0.05 \mathrm{M}$ Tris, $\mathrm{pH}$ 8.1, $\mathrm{MgCl}_{2} 1 \mathrm{mM}, \mathrm{NaCl} 0.15 \mathrm{M}, 0.05 \%$ Tween $20,0.02 \% \mathrm{NaN}_{3}$, and $1 \% \mathrm{BSA}$ ) and incubated at room temperature for $2 \mathrm{~h}$. The plate was then washed with rinse buffer and incubated with a second $\mathrm{Ab}$ (goat anti-human IgG-, IgM-, or IgA-alkaline phosphatase conjugate, 1:1000 to 1:3000 dilution, Sigma Chemical Co., St. Louis, MO). The color was developed by adding substrate solution (104 Phosphatase Substrate Tablet 1 tablet $/ 5 \mathrm{~mL}$, Sigma). $\mathrm{OD}$ at $410 \mathrm{~nm}$ was read by an ELISA reader. Monoclonal human $\mathrm{IgG}, \mathrm{IgA}$, and $\mathrm{IgM}$ were used as standards in each assay. In preliminary experiments with five males and five females, individuals of both sexes showed equivalent responses to PWM and demonstrated increases in Ig production with the addition of RNA.

Reagents. SAC (Pansorbin, Calbiochem, San Diego, CA), PWM (GIBCO-BRL, Gaithersburg, MD), and TNP-LPS (Sigma) were obtained from the commercial sources indicated. $\mathrm{KLH}$ (Calbiochem) and Ficoll (Sigma) were modified with TNP in our laboratory as described elsewhere (16). In this study, the yeast RNA used for the production of the commercially available formula (IMPACT) were kindly provided by Sandoz Nutrition Corp., Minneapolis, MN. The components of this RNA preparation had already been extensively analyzed by the company (RNA 91\%, hydrolyzate of RNA $5.0 \%$, cold acid-soluble fraction including sodium salts of mononucleotides $1.0 \%$, sugars $0.5 \%$, and $\mathrm{NaCl} 2.5 \%$ ). No significant endotoxin contamination was detected; endotoxin contained was less than $1 \mathrm{ng} / \mathrm{L}$ in $10 \mathrm{~g} / \mathrm{L}$ RNA solution (Toxicolor system, Seikagaku Kogyo, Tokyo, Japan). Furthermore, in our preliminary three experiments, the addition of polymyxin $B(50 \mathrm{mg} / \mathrm{L})$ did not inhibit the actions of RNA in an in vitro Ig production assay by HPBMNC. RNA preparations were kept at $-20^{\circ} \mathrm{C}$ as in lyophilized forms and dissolved into diethylpyrocarbonate-treated water on the day of the experiment. Food and Drug Administration approved mononucleotides (AMP, cytidine 5'-phosphate, GMP, inosine monophosphate, and uridine phosphate that were used for the production of the infant formula (SMA) were kindly provided by Wyeth-Ayerst Research, Philadelphia, PA. Stock solution of mononucleotide mixture was prepared as follows: cytidine $5^{\prime}$ phosphate $16.5 \mathrm{~g} / \mathrm{L}$, uridine phosphate $4 \mathrm{~g} / \mathrm{L}$, AMP $5 \mathrm{~g} / \mathrm{L}$, GMP $2 \mathrm{~g} / \mathrm{L}$, and inosine monophosphate $2 \mathrm{~g} / \mathrm{L}$ in diethylpyrocarbonate-treated water. The stock solution was then aliquoted and kept at $-20^{\circ} \mathrm{C}$ until the time of use. Typically, mononucleotide mixture used in the experiments was either a 1:1000 or a 1:10000 dilution of this mixture (1:100 of this stock solution corresponds to the concentration of each mononucleotide contained in human breast milk).

Chemical Modification of RNA. The yeast RNA preparations were chemically modified as follows: 1 ) RNA solution (2 g/L) was dialyzed and lyophilized without any other treatment (control). 2) Cytosine bases of RNA were modified with $2 \mathrm{M}$ $\mathrm{NH}_{2} \mathrm{OH} \cdot \mathrm{HCl}$, pH 6.2 , for $5 \mathrm{~d}$ at $30^{\circ} \mathrm{C}$, which resulted in the formation of hydroxylaminated cytosine bases. 3) Uracil bases of RNA solutions were modified with $2 \mathrm{M} \mathrm{NH}_{2} \mathrm{OH} \cdot \mathrm{HCl}, \mathrm{pH}$ 9.0 , for $5 \mathrm{~d}$ at $30^{\circ} \mathrm{C}$, which resulted in the formation of ribose oxime derivatives via ribosyl urea (18). 4) RNA was decomposed with alkaline (Korthoff buffer: $0.1 \mathrm{M} \mathrm{Na}_{2} \mathrm{CO}_{3}-0.1 \mathrm{M} \mathrm{HCl}, \mathrm{pH}$ 11.0 ) for $20 \mathrm{~min}$ at $70^{\circ} \mathrm{C}$, which resulted in $10 \%$ breakage of phosphodiester bonds in RNA (19). 5) RNA was decomposed with Korthoff buffer for $2 \mathrm{~h}$ at $70^{\circ} \mathrm{C}$, which resulted in $50 \%$ breakage of phosphodiester bonds in RNA (19). 6) RNA was oxidized with $26.4 \mathrm{mM} \mathrm{KMnO}_{4}, \mathrm{pH} 6.7$, for $30 \mathrm{~min}$ at $0^{\circ} \mathrm{C}$, which was reported to cause decomposition of most pyrimidine bases of nucleotides and $20 \%$ of pyrimidine bases in transfer RNA (20). RNA samples were then dialyzed against $0.05 \mathrm{M}$ $\mathrm{NaCl}$ one time, dialyzed against sterile distilled water three times, lyophilized, and kept at $-20^{\circ} \mathrm{C}$ until the time of use.

Statistics. Statistical analyses were performed with $t$ test or 
Welch's test based on the results of $F$ test. $p<0.05$ was considered to be significant.

\section{RESULTS}

In vitro Ig production by HPBMNC in RNA-supplemented culture. Ig production by HPBMNC was potentiated by various stimuli as shown in Figure 1 in RNA-supplemented culture conditions. After $7 \mathrm{~d}$ of incubation, IgM, IgG, and IgA levels of the culture supernatant were measured. Results of six experiments were summarized in Figure 1. In each experiment, the blood sample was drawn from a different individual. The RNA supplementation significantly increased IgM production $(p<$ 0.05 ) when HPBMNC were stimulated by PWM, which is a Tdependent stimulant, and TNP-KLH, which is a TD-Ag (Fig. $1 A$, Table 1). PWM- and TNP-KLH-potentiated IgG produc-
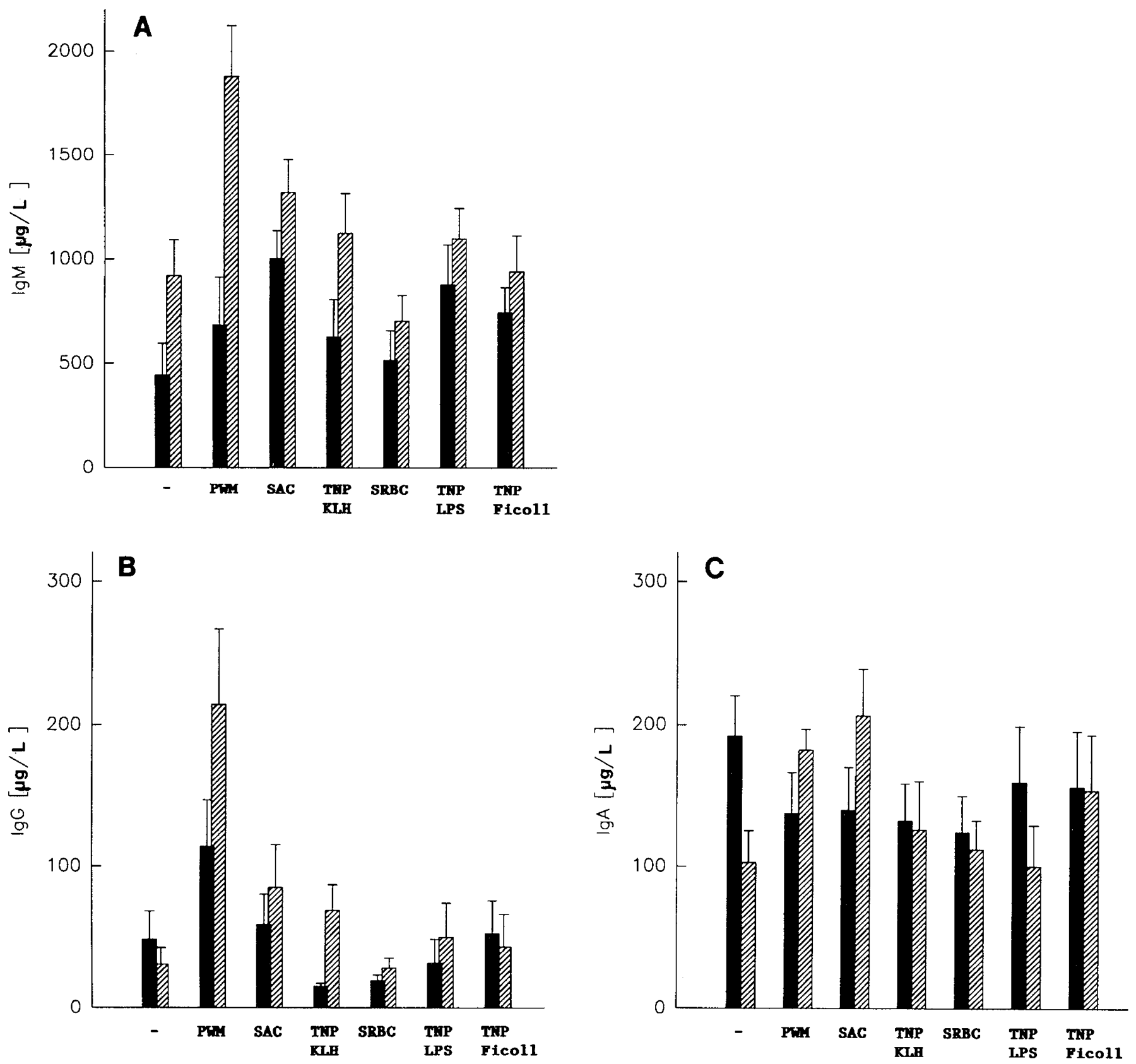

Fig. 1. IgM, IgG, and IgA production by HPBMNC after $7 \mathrm{~d}$ of culture in the medium with or without RNA supplementation. Ig production was potentiated with medium alone as control, PWM (1:1000), SAC $(0.005 \%)$, TNP-KLH $(10 \mathrm{mg} / \mathrm{L})$, SRBC $(0.05 \%)$, TNP-LPS (2 mg/L), and TNP-Ficoll $(10 \mathrm{mg} / \mathrm{L})$ in the absence of RNA $(\mathbf{\square})$ or in the presence of RNA $(0.1 \mathrm{~g} / \mathrm{L})(\mathbb{Q})$. IgM $(A), \operatorname{IgG}(B)$, and IgA $(C)$ levels in the culture supernatant were measured by ELISA, and each data point represents the average \pm SEM of Ig levels in each setting in five to six experiments. tion also increased significantly in the presence of the RNA preparations (Fig. $1 B$ ). SRBC, another TD-Ag, did not potentiate Ig production by HPBMNC very well in this culture system, and RNA did not further enhance IgM or IgG production potentiated by SRBC. IgM production potentiated by T-independent stimuli (SAC, TNP-LPS, and TNP-Ficoll) appeared to be augmented modestly by RNA, but this was not statistically significant (Fig. $1 A$ ). IgG production potentiated by these $\mathrm{T}$-independent stimuli was not augmented at all by RNA/nucleotides (Fig. $1 B$, Table 1). Interestingly, spontaneous IgM production appeared to increase under the RNA-supplemented culture conditions. This was observed fairly consistently (Figs. 1, $3 A$, and $5 A$, Table 1). In contrast, spontaneous IgA production was rather decreased in the presence of RNA/nucleotides (Fig. 1C). All stimulants used were generally ineffective to potentiate appreciable IgA production by HPBMNC in vitro, and the presence of RNA in the 
Table $1 . I g$ production by HPBMC in vitro in response to PWM plus chemically modified nucleotides

\begin{tabular}{|c|c|c|c|}
\hline \multirow[b]{2}{*}{ HPBMNC stimulants } & \multicolumn{3}{|c|}{ Ig production in vitro } \\
\hline & $\operatorname{IgM}(\mathrm{mg} / \mathrm{L})$ & $\mathrm{IgG}(\mathrm{mg} / \mathrm{L})$ & $\operatorname{IgA}(\mathrm{mg} / \mathrm{L})$ \\
\hline & $748 \pm 120$ & $46.7 \pm 30.5$ & $170.1 \pm 13.5$ \\
\hline $\operatorname{RNA}(0.1 \mathrm{~g} / \mathrm{L})$ & $1150 \pm 81$ & $60.0 \pm 34.0$ & $130.5 \pm 8.2$ \\
\hline PWM (1:1000) & $969 \pm 347$ & $189.8 \pm 87.4$ & $137.4 \pm 18.7$ \\
\hline $\begin{array}{c}\text { PWM + RNA } \\
(0.1 \mathrm{~g} / \mathrm{L})^{*}\end{array}$ & $2551 \pm 392$ & $326.4 \pm 97.1$ & $166.0 \pm 17.8$ \\
\hline $\begin{array}{l}\text { PWM + RNA } 1 \\
(0.1 \mathrm{~g} / \mathrm{L})\end{array}$ & $2560 \pm 282$ & $376.4 \pm 83.2$ & $152.2 \pm 33.3$ \\
\hline $\begin{array}{l}\text { PWM + RNA } 2 \\
(0.1 \mathrm{~g} / \mathrm{L})\end{array}$ & $1633 \pm 416$ & $216.3 \pm 59.7 \dagger$ & $126.5 \pm 17.1$ \\
\hline $\begin{array}{l}\text { PWM + RNA } 3 \\
(0.1 \mathrm{~g} / \mathrm{L})\end{array}$ & $1374 \pm 342 \ddagger$ & $220.2 \pm 60.5 \dagger$ & $128.5 \pm 17.5$ \\
\hline $\begin{array}{l}\text { PWM + RNA } 4 \\
\quad(0.1 \mathrm{~g} / \mathrm{L})\end{array}$ & $1391 \pm 392 \ddagger$ & $221.9 \pm 57.2 \dagger$ & $177.7 \pm 72.9$ \\
\hline $\begin{array}{l}\text { PWM + RNA } 5 \\
(0.1 \mathrm{~g} / \mathrm{L})\end{array}$ & $1314 \pm 354 \ddagger$ & $211.9 \pm 85.7 \S$ & $128.2 \pm 15.8$ \\
\hline $\begin{array}{l}\text { PWM + RNA } 6 \\
(0.1 \mathrm{~g} / \mathrm{L})\end{array}$ & $1540 \pm 334 \ddagger$ & $255.0 \pm 48.7 \dagger$ & $136.5 \pm 7.6$ \\
\hline
\end{tabular}

* RNA preparations were dissolved into sterile distilled water $(2 \mathrm{~g} / \mathrm{L})$ and chemically modified as follows: RNA 1, solution was dialyzed and lyophilized as described below without any other treatment (positive control); RNA 2, cytosine bases were modified with $2 \mathrm{M} \mathrm{NH}_{2} \mathrm{OH} \cdot \mathrm{HCl}$, $\mathrm{pH} 6.2$, for $5 \mathrm{~d}$ at $30^{\circ} \mathrm{C}$; RNA 3, uridine bases were modified with $2 \mathrm{M}$ $\mathrm{NH}_{2} \mathrm{OH} \cdot \mathrm{HCl}, \mathrm{pH} 9.0$, for $5 \mathrm{~d}$ at $30^{\circ} \mathrm{C}$; RNA 4 was decomposed with alkaline (Korthoff buffer: $0.1 \mathrm{M} \mathrm{Na}_{2} \mathrm{CO}_{3}-0.1 \mathrm{M} \mathrm{HCl}, \mathrm{pH} 11.0$ ) for 20 min at $70^{\circ} \mathrm{C}$; RNA 5 was decomposed with Korthoff buffer for $2 \mathrm{~h}$ at $70^{\circ} \mathrm{C}$; and RNA 6 was oxidized with $\mathrm{KMnO}_{4}(26.4 \mathrm{mM}, \mathrm{pH} 6.7)$ for 30 $\min$ at $0^{\circ} \mathrm{C}$. All RNA samples were then dialyzed against $0.05 \mathrm{M} \mathrm{NaCl}$ one time against distilled water three times and then lyophilized. The data shown in the table summarizes six experiments. In each experiment, HPBMNC were obtained from a different normal adult volunteer. The results were expressed as mean Ig levels $\pm \operatorname{SEM}(n=6)$.

† Significantly decreased compared with the values obtained in the presence of control RNA sample $1(p<0.005)$.

$\ddagger$ Significantly decreased compared with the values obtained in the presence of control RNA 1 without treatment $(p<0.05)$.

$\S$ Significantly decreased compared with the values obtained in the presence of control RNA sample $1(p<0.02)$.

culture did not significantly alter IgA production irrespective of the stimulants used.

In summary, the RNA preparations seem to preferentially augment IgG and $\operatorname{IgM}$ production in response to $\mathrm{T}$-dependent stimuli in humans.

Effects of chemically modified RNA on Ig production by $H P B M N C$. RNA samples were modified of uridine or cytosine bases, degraded with alkaline in various degrees, or oxidized with $\mathrm{KMnO}_{4}$ as detailed in Materials and Methods. After these treatments, RNA samples were dialyzed extensively and lyophilized. These chemically modified RNA samples were subjected for their actions on Ig production by HPBMNC when potentiated with PWM (1:1000). During the period of dialysis, oligonucleotides smaller than 4 bp were considered to be lost because the cutting molecular weight of dialyzing membrane used was 1000 . The results of six experiments are summarized in Table 1. The modification of RNA appeared not to change IgA production significantly; however, enhancing actions of RNA/nucleotides on IgM and IgG production by HPBMNC were reduced considerably by these treatments (Table 1). This was especially evident when RNA samples were degraded with alkaline (Korthoff buffer, $\mathrm{pH} 11$ ) for $2 \mathrm{~h}$ at $70^{\circ} \mathrm{C}$ (corresponds to RNA sample 5 in Table 1). Control RNA, which underwent dialysis and lyophilization only, without any chemical modification, did not lose most of its enhancing actions compared with untreated RNA samples (Table 1).
Effects of mononucleotide mixture on in vitro Ig production by $H P B M N C$. We also examined whether mononucleotides exert similar actions on Ig production by HPBMNC as observed in animal studies (12). A mononucleotide mixture was patterned after the contents of nucleotides in breast milk as shown in Materials and Methods. A 1:1000 dilution of stock solution of the mononucleotide mixture, which may be close to the concentration of mononucleotides in the gut of breast-fed infants, only marginally enhanced $\operatorname{IgM}$ and $\operatorname{IgG}$ production in response to PWM $(p>1.0)$ (Fig. 2). When a higher concentration of the mononucleotide mixture was added to the culture $(1: 100$ to 1:500 dilution of stock solution), Ig production in response to various stimuli did not increase as well. An increase of spontaneous IgM production was not observed in the presence of a lower concentration of mononucleotide mixture (10000 to 100000 dilution of stock solution). When Ig production was
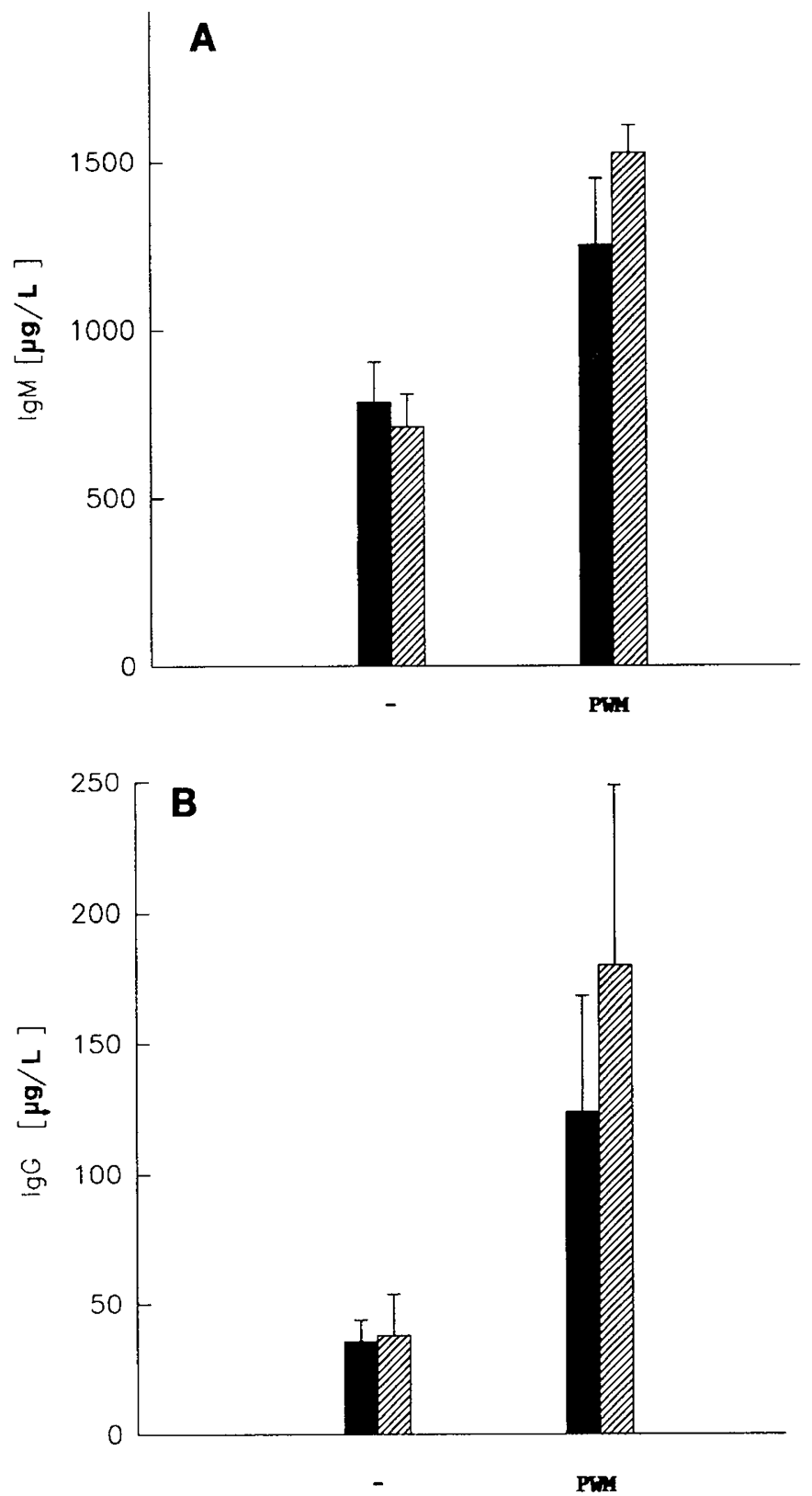

Fig. 2. $\operatorname{IgM}(A)$ and $\operatorname{IgG}(B)$ production by HPBMNC in the presence $(\mathbb{Q})$ or absence $(\varpi)$ of mononucleotide mixture $(1: 1000)$ when potentiated with medium alone or PWM $(1: 1000)$. The culture supernatant was harvested $7 \mathrm{~d}$ after the culture, and these results were the summary of four experiments. Each data point represents mean \pm SEM of Ig levels in each setting. 
potentiated by other stimuli, no significant enhancement of Ig production was observed in the presence of the mononucleotide mixture (200 to 100000 dilution of stock solution).

Dose responses to RNA and time course of RNA supplementation to culture. We studied the changes of Ig production (to PWM 1:1000) in response to various doses of RNA. The results of five experiments are summarized in Figure 3. IgM and IgG production potentiated by PWM appeared to be dependent on the dose of RNA supplemented to the culture. Spontaneous IgM production appeared to increase modestly as well in a dose dependent manner to RNA. IgA production did not show significant changes in the presence of various doses of RNA. We then studied the Ig production by HPBMNC after $4,7,10$, and $14 \mathrm{~d}$ of the culture in the presence of medium alone, RNA $(0.1 \mathrm{~g} / \mathrm{L})$, PWM (1:1000), and RNA plus PWM. The increase of IgM and
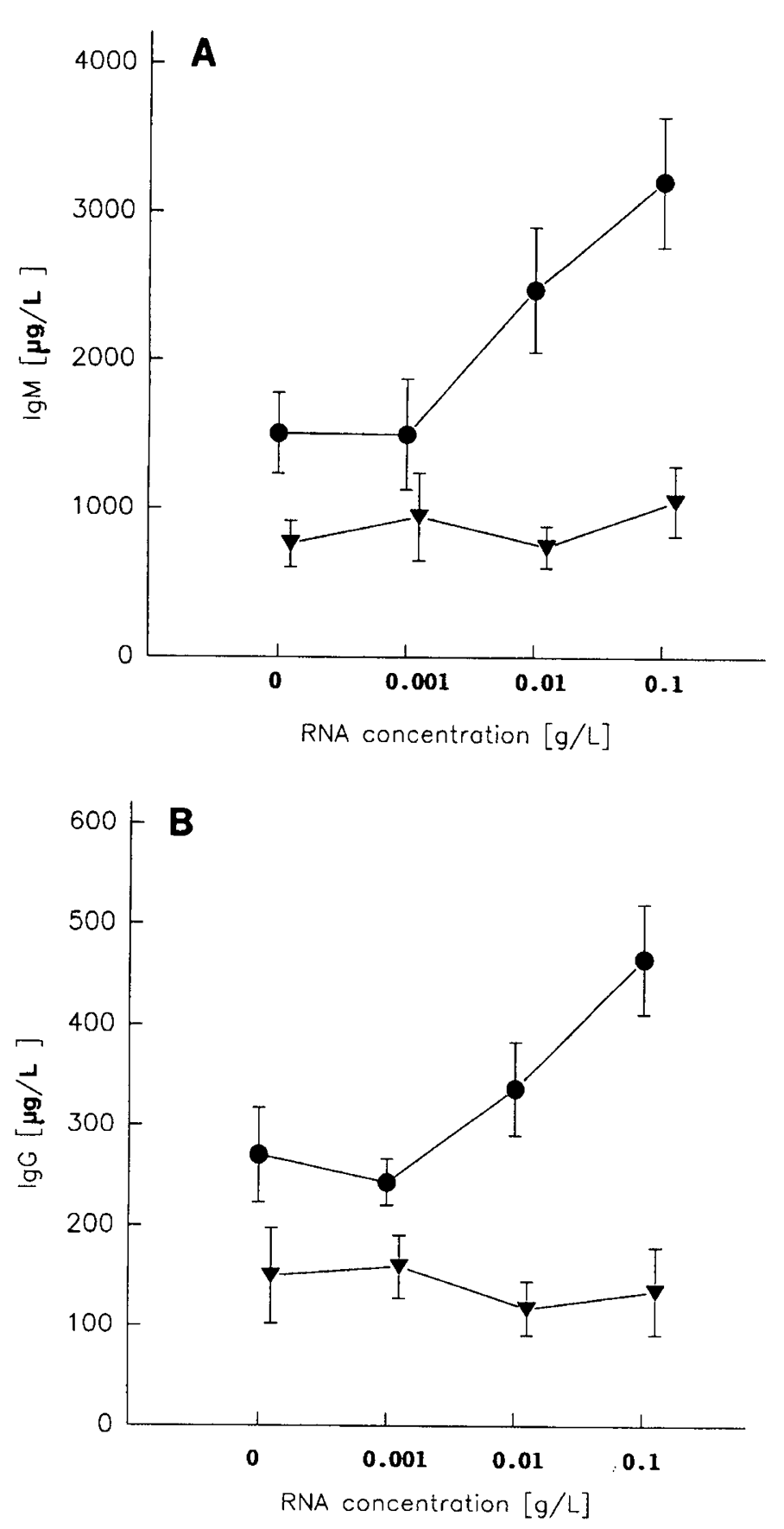

IgG in the presence of RNA was apparent $7 \mathrm{~d}$ after the culture and still observed $14 \mathrm{~d}$ after the culture (data not shown).

Next, the effects of the time course of RNA supplementation $(0.1 \mathrm{~g} / \mathrm{L})$ were examined by adding RNA to the culture medium on $\mathrm{d} 0,1,3,5$, and 7 of the culture of HPBMNC. Ig levels of supernatant harvested on $\mathrm{d} 8$ of the culture were measured. PWM (1:000) were used to potentiate Ig production by HPBMNC. Figure 4 presents the data obtained in one representative experiment of such studies, which showed that the enhancing action of RNA/nucleotides on in vitro $\operatorname{IgM} / \mathrm{IgG}$ production was significantly reduced when they were supplemented at $\mathrm{d} 3$ of the culture or later. Similar results were obtained in two other experiments.

Effects of depletion of $T$ cells on action of RNA on $\operatorname{Ig} M / \operatorname{Ig} G$ production in response to $P W M$. IgM and $\mathrm{IgG}$ production by

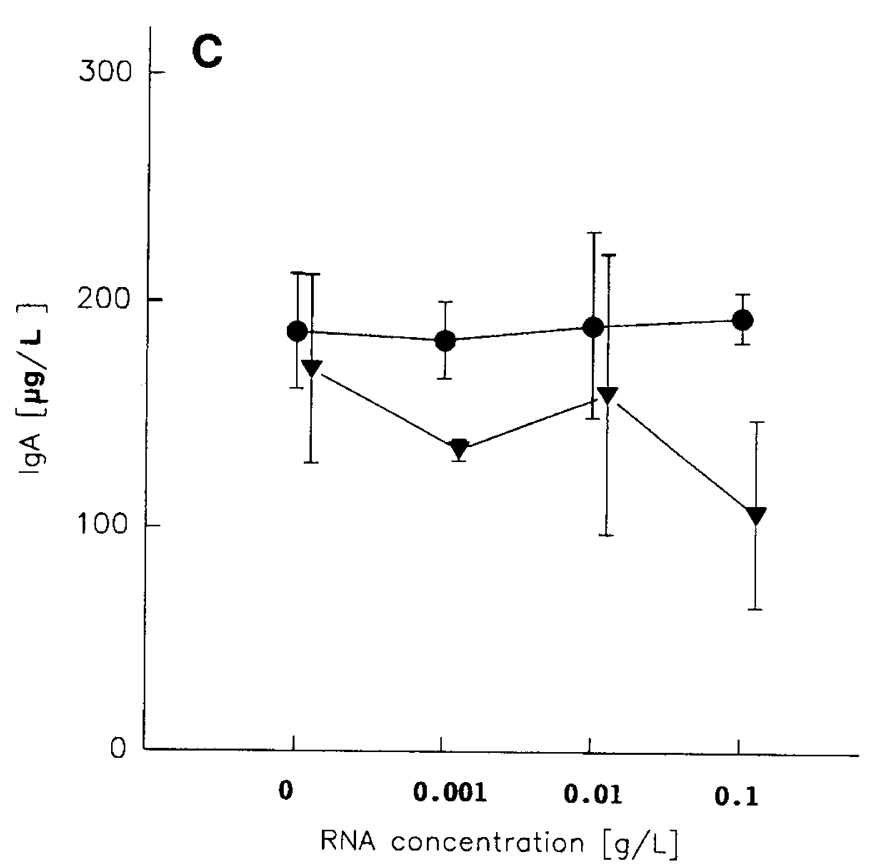

Fig. 3. IgM $(A), \operatorname{lgG}(B)$, and $\operatorname{IgA}(C)$ production by HPMNC in the presence of various doses of RNA after 7 of culture. Each data point represents the average \pm SEM Ig levels in five experiments. Ig production was measured when cells were cultured in the medium alone $(\nabla)$ or stimulated with PWM $(1: 1000)(\bullet)$. 


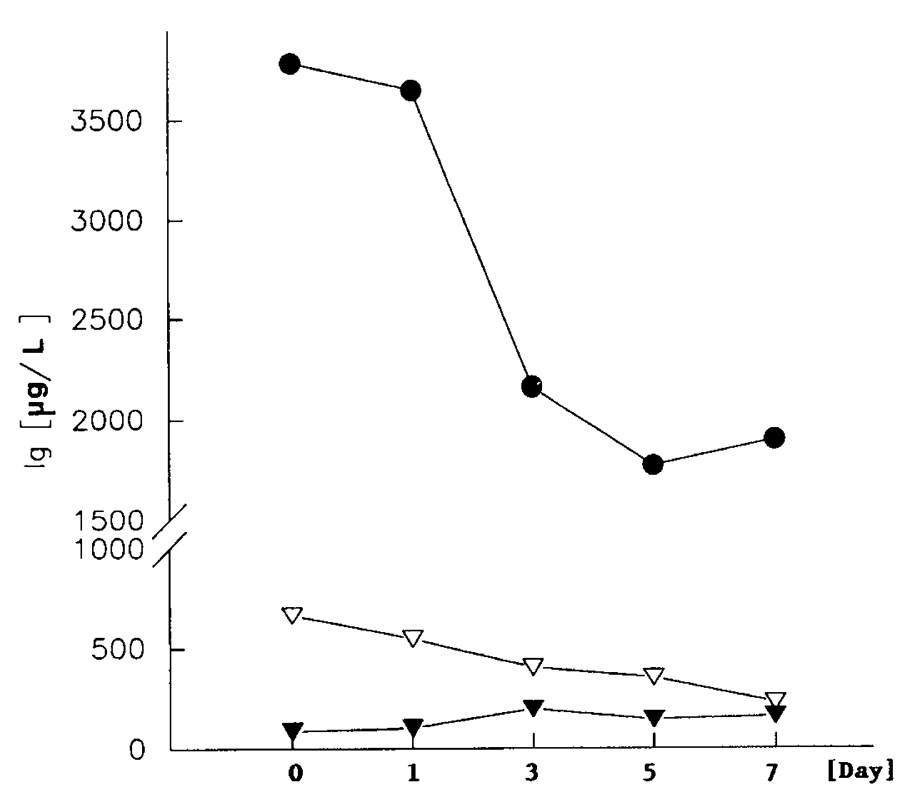

Fig. 4. $\operatorname{IgM}(\bullet), \operatorname{IgG}(\nabla)$, and $\operatorname{IgA}(\boldsymbol{\nabla})$ production after $8 \mathrm{~d}$ of culture of HPMNC in the presence of PWM (1:1000). RNA samples were added to the medium on $\mathrm{d} 0,1,3,5$, and 7 of the culture. After $3 \mathrm{~d}$ of the culture, the addition of RNA seemed to have no action on the in vitro Ig production by HPBMNC. These are results of one representative experiment in three such experiments. Each data point represents the average of results of duplicate samples.

unseparated HPBMNC, T-depleted HPBMNC, and T-depleted HPBMNC coincubated with T-cell-enriched HPBMNC in a diffusion chamber was examined. Cells were incubated with medium alone, RNA (0.1 g/L), PWM (1:1000), and RNA plus PWM. When T-depleted HPBMNC were incubated with T-cellenriched HPBMNC, no direct contact was permitted between these two cell populations in the diffusion chamber (Transwell, Costar). The ratio of T-enriched HPBMNC and T-depleted HPBMNC was adjusted to approximately $4: 1$ based on normal ratios of $\mathrm{T}$ and $\mathrm{B}$ cells in human peripheral blood. Figure 5 shows the results of one representative experiment among three such experiments. As expected, the depletion of $\mathrm{T}$ cells completely abolished the response to PWM. The enhancing action of RNA/nucleotides on Ig production by HPBMNC in the presence of PWM was also lost. Coculture of $T$ cell-depleted HPBMNC and T-cell-enriched HPBMNC in a diffusion chamber did not restore the enhancing action of RNA on Ig production by HPBMNC. However, spontaneous IgM production increased modestly in the RNA-supplemented culture even if T cells were absent. This may indicate the direct action(s) of RNA/nucleotides on B cells or other lineage cells.

\section{DISCUSSION}

Human breast milk contains significant amounts of nucleotides. Nonprotein nitrogen consists of up to $30 \%$ of total nitrogen in breast milk, and nucleotides may account for up to $20 \%$ of its nonprotein nitrogen (3). However, nucleotides are not regularly supplemented in standard infant formulas partly because of our lack of understanding of their physiologic roles. In well-nourished animals, less than $5 \%$ of dietary nucleotides seem to be integrated into the tissue nucleic pool $(1,2)$. However, Leleiko et al. $(21)$ have shown that in rats given a purine antimetabolite (6-mercaptopurine) or fed a nucleotide-free diet, RNA contents of the small intestine decrease significantly, suggesting that cells may preserve DNA content at the expense of RNA/nucleotides. Therefore, it seems reasonable to speculate that dietary nucleotides will be used in higher amounts when de novo synthesis of nucleotides by the liver is insufficient. This may occur at the time of rapid growth in patients with liver dysfunction and those recovering
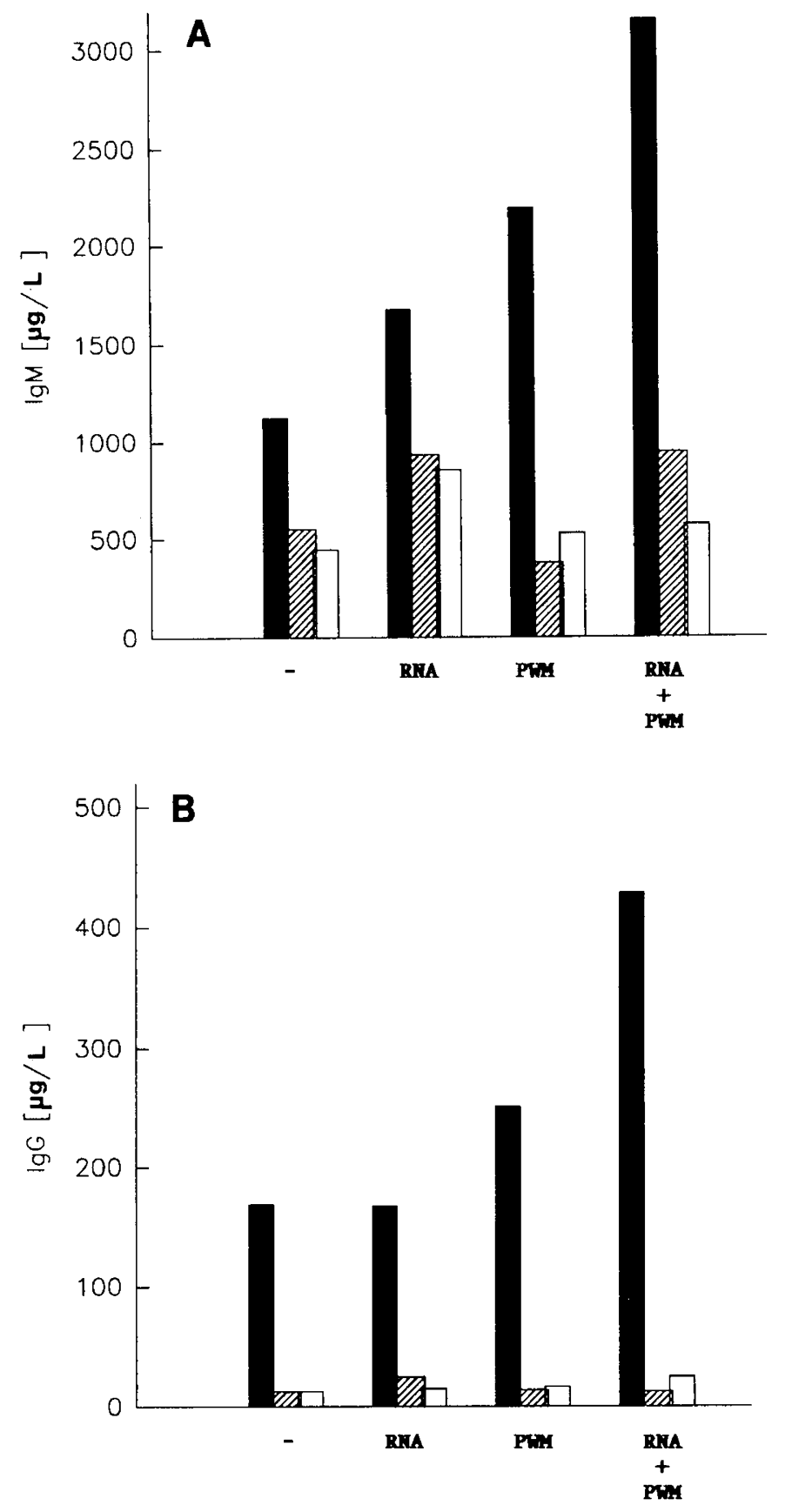

Fig. 5. $\operatorname{IgM}(A)$ and $\operatorname{IgG}(B)$ production by HPBMNC when they were stimulated with medium alone, RNA $(0.1 \mathrm{~g} / \mathrm{L})$, PWM $(1: 1000)$, and RNA plus PWM. Ig production by unseparated HPBMNC ( $\mathbf{}), \mathrm{T}$ depleted HPBMNC $(\mathbb{Q})$, and T-depleted HPMNC cocultured with Tenriched HPBMNC $(\square)$ in the diffusion chamber. These are results of one representative experiment among four experiments. Each data point represents the average Ig level of duplicate samples.

from massive tissue injury. Evidence so far indicates that exogenous nucleotides may augment the growth of intestinal mucosa, enhance intestinal iron absorption, and promote the growth of bifidobacteria (3-6), which may have favorable effects in early infancy.

Neonates are born with a relatively immature immune system, and rapid maturation and expansion of lymphoid organs takes place in early infancy, especially in the GI tract. However, lymphocytes are relatively incapable of synthesizing nucleotides by themselves and appear largely dependent on those produced by other organs, mainly the liver. Thus, exogenous nucleotides may be an important factor for maintaining optimal immune 
functions in certain circumstances. In animals fed nucleotidefree diets, decreased immune functions have been demonstrated associated with delayed allograft rejection and increased mortality in systemic infections caused by certain pathogens $(7-11,22)$. In humans, Carver et al. (23) have shown that natural killer cell activity and IL-2 production are higher in breast-fed or nucleotide-fortified formula-fed infants compared with infants fed regular infant formula. These results may favor the physiologic significance of dietary nucleotides to the immune system, especially in early infancy. However, information regarding the mechanisms of the immunomodulating actions of nucleotides is still surprisingly scarce.

Our previous attempts to elucidate the immunomodulating actions of nucleotides on murine lymphocytes in vitro have shown that yeast RNA preparations strikingly enhance $\mathrm{Ig}$ and $\mathrm{Ab}$ production in vitro in response to $\mathrm{TD}-\mathrm{Ag}$ in normal $\mathrm{B} 6$ mice (12). This enhancing action of RNA was considerably reduced by ribonuclease treatment and may be partially reproduced by certain mononucleotides (12). Furthermore, RNA appear not to augment polyclonal $\mathrm{B}$ cell activation in both normal and autoimmune strains of mice but preferentially enhance specific $A b$ production against TD-Ag exerting their actions in the initial period of antigen priming in the culture (14). To extend this study to humans, we examined in vitro Ig production by HPBMNC under RNA-supplemented culture conditions.

The most significant finding in this study is that RNA impressively augment IgM and IgG production potentiated by PWM and TNP-KLH, both of which are T-dependent stimuli. The enhancing actions of RNA on IgM and IgG production were observed in a dose-dependent manner and were almost completely abolished when RNA samples were chemically modified or degraded, as shown in Results. The contamination of endotoxin of RNA preparations was minimal, and the actions of RNA on Ig production by HPBMNC were not inhibited by polymyxin B, a specific endotoxin inhibitor, in our initial studies, as stated in Materials and Methods. In previous studies, we have shown that the RNA preparations used in this study consist of nucleotides of $<1000 \mathrm{bp}$ when denatured with glyoxal (12). In the process of dialysis during the chemical modification of RNA, very small nucleotides $(<4 \mathrm{bp})$ were lost because the cutting molecular weight of dialyzing membrane was 1000 . The control RNA samples, which underwent the dialysis step without any chemical modification, were as effective as untreated RNA samples in enhancing Ig production by HPBMNC. A mononucleotide mixture prepared based on the contents of mononucleotides in breast milk was only marginally effective in enhancing Ig production by HPBMNC. Thus, in this culture system, the enhancing actions of RNA preparations seemed to be largely attributable to polynucleotides larger than 4 bp but probably smaller than $1000 \mathrm{bp}$. However, these results do not necessarily undermine the nutritional significance of mononucleotides in breast milk, because it is quite possible that mononucleotides may be quickly incorporated into the tissue nucleotide pool, and larger nucleotides may be synthesized in the body at significant speed.

Some proteoglycans that coprecipitate with RNA may potentiate Ig production (24). However, the amount necessary to potentiate Ig production is relatively high, and considering that the yeast RNA preparation we used has a negligible amount of protein contamination, it is unlikely that the contamination of proteoglycans in the RNA preparations is partially attributable to the enhancing actions of RNA on Ig production by HPBMNC observed in this study.

In our previous study of animal models, we obtained a more linear dose response in an in vitro $\mathrm{Ab}$ production assay in response to TD-Ag compared with the results of Ig production by HPBMNC in this study. In animal models, we used a plaqueforming cell assay, which detects $\mathrm{B}$ cells producing specific Ab. When we tested the total Ig production in animal models, we obtained a dose-response curve similar to that obtained in hu- mans. Thus, this difference may be related to the variation in methodology. It may be possible that when B cells are activated to produce Ig, total Ig production will then be suppressed by secondary negative feedback mechanisms (25).

The depletion of $\mathrm{T}$ cells from spleen cell suspensions also abolished the enhancing actions of nucleotides on IgG and IgM production (in response to PWM). Furthermore, it seemed that RNA must be present from the initial period of B-cell activation, and $T$ cells are also required to contact other lineage cells directly to obtain optimal enhancing actions by RNA. These results were fairly consistent with those obtained in animal studies (12-14).

The GI tract is the major organ constantly exposed to foreign antigens. In early infancy, such constant antigen stimuli may be problematic, considering the immature immune functions at that age. Enhanced Ig production in response to T-dependent stimuli by nucleotides may be beneficial at this age in enhancing the production of specific antibodies. However, in this study, the data were generated by studying HPBMNC from adult volunteers. Thus, the effects of nucleotides should also be tested on immature human lymphocytes to further confirm such an assumption. Exogenous nucleotides may also have a significant impact in other circumstances in which optimal humoral immune responses are favored, such as in patients recuperating from major surgery, or system infections and those suffering from severe immunodeficiency, including AIDS patients.

IgA production by HPBMNC was not significantly altered with the supplementation of RNA and mononucleotides to the culture. Because secretory IgA is the major Ab to be engaged in the first-line defense mechanisms of the GI tract, this finding may undermine the nutritional significance of nucleotides in human breast milk. On the other hand, serum IgA levels are quite low in early infancy and usually do not reach adult levels before $2 \mathrm{y}$ of age. In early infancy, roles of secretory IgA might be smaller compared with those in adults. Moreover, because we have not studied the actions of nucleotides on secretory IgA production, these results do not exclude the possible immunomodulating actions of nucleotides on IgA.

In summary, this study demonstrated the possible favorable actions of exogenous nucleotides on Ig production in humans, and these results may further support the nutritional significance of nucleotides in human breast milk.

Acknowledgment. The authors thank Dr. Jerome Licari for providing RNA preparations (used for the production of IMPACT elementary formula) and Dr. Eric L. Lien for providing Food and Drug Administration-certified synthetic mononucleotides (used for the production of SMA infant formula). The authors also thank Drs. M. Georgieff and G. Minervini for helpful reviews.

\section{REFERENCES}

1. Sonoda T, Tachibana M 1978 Metabolic rate of pyrimidines and purines in dietary nucleic acids ingested by mice. Biochim Biophys Acta 521:55-66

2. Burridge PW, Woods RA, Henderson JF 1976 Utilization of dietary nucleic acid purine for nucleotide and nucleic acid synthesis in the mouse. Can J Biochem 54:500-506

3. Uany R 1989 Dietary nucleotide and requirements in early life. In: Lebenthal E (ed) Textbook of Gastroenterology and Nutrition in Infancy, 2nd Ed. Raven Press, New York, pp 265-280

4. Gil A, Coval E, Martinez A, Molia JA 1986 Effects of dietary nucleotides on the microbial pattern of feces of at term newborn infants. J Clin Nutr Gastroenterol 1:34-38

5. Uany R, Stringel G, Thomas R, Quan R 1990 Effect of dietary nucleotides on growth and maturation of the developing gut in the rat. J Pediatr Gastroenterol 10:497-503

6. Sanchez-Pozo A, Rita ML 1986 Effects of dietary nucleotides upon lipoprotein pattern of newborn infants. Nutr Res 6:763-771

7. Rudolph FB, Kulkarni AD, Fanslow WE, Pizzini RP, Kumar S, Van Buren CT 1990 Role of RNA as a dietary source of pyrimidines and purines in immune function. Nutrition 6:45-52

8. Kulkarni AD, Fanslow WC, Rudolph FB, Van Buren CT 1988 Modulation of delayed hypersensitivity in mice by dietary nucleotide restriction. Transplantation 44:847-849

9. Van Buren CT, Kulkarni AD, Fanslow WC, Rudolph FB 1985 Dietary 
nucleotide, a requirement for helper/induced T lymphocytes. Transplantation 40:694-697

10. Kulkarni AD, Fanslow WC, Rudolph FB, Van Buren CT 1986 Effect of dietary nucleotide on response to bacterial infections. J Parenter Enteral Nutr 10:169-171

11. Fanslow WC, Kulkarni AD, Van Buren CT, Rudolph FB 1988 Effect of nucleotide restriction and supplementation on resistance to experimental murine candidiasis. J Parenter Enteral Nutr 12:49-52

12. Jyonouchi H, Hill RJ, Good RA 1992 RNA/nucleotide enhances antibody production in vitro and is moderately mitogenic to murine spleen lymphocytes. Proc Soc Exp Biol Med 200:101-108

13. Jyonouchi H, Zhang L, Tomita Y 1992 RNA/nucleotide and astaxanthin enhance in vitro $\mathrm{Ab}$ production to $\mathrm{T}$ dependent antigens (TD-Ag) but not to $\mathrm{T}$ independent antigens ( $\mathrm{TI}-\mathrm{Ag}$ ) or do not further enhance polyclonal $\mathrm{B}$ cell activation in NZB mice. FASEB J 7:A963(abstr)

14. Jyonouchi H, Hill RJ, Voss RM, Ishii E 1993 Immunomodulating actions of RNA and nucleotides on murine lymphocytes in vitro. Augmentation of antibody production to $T$ dependent antigens and expansion of $T$ helper cells. J Nutr Immunol (in press)

15. Jyonouchi H, Voss RM, Good RA 1987 IL-1 like activities present in murine amniotic fluid. A significantly larger amount of IL-1 beta-like activity is present in the amniotic fluid of autoimmune NZB mice. J Immunol 138:1891-1899

16. Cambier JC, Monroe JG, Neale MJ 1982 Definition of conditions which facilitate antigen specific activation of the majority of isolated trinitropheno binding B cells. J Exp Med 156:1635-1649
17. Small TN, Keever CA, Weiner-Fedus S, Heller G, O'Reilly RJ, Flomenberg N 1990 B-cell differentiation following autologous, conventional, or T-cell depleted bone marrow transplantation: a recapitulation of normal B-cell ontogeny. Blood 76:1647-1656

18. Schuster 1961 The reaction of Tobacco mosaic virus ribonucleic acid with hydroxylamine. J Mol Biol 3:447-457

19. Bock RM 1967 Controlled partial hydrolysis of RNA. In: Colowick SP, Kaplan NO (eds) Methods in Enzymology, Vol 12. Academic Press, New York, pp 218-221

20. Hayatsu $H$, and Ukita $T 1967$ The selective degradation of pyrimidines in nucleic acids by permanganate oxidation. Biochem Biophys Res Commun 29:561-556

21. Leleiko NZ, Martin BA, Walsh M, Kazlow P, Rabinowitz S, Sterinb K 1987 Tissue specific gene expression results from a purine and pyrimidine-free diet and 6-mercaptopurine in the rat small intestine and colon. Gastroenterology 93:1014-1020

22. Van Buren CT, Kulkarini AD, Rudolph FB 1987 Synergistic effect of nucleotide-free diet and cyclosporin on allograft survival. Transplant Proc 5(suppl):57-59

23. Carver JD, Pimentel B, Cox WI, Barness LA 1991 Dietary nucleotide effects upon immune function in infants. Pediatrics 88:359-363

24. Sugawara I, Ishizaka S 1982 Polysaccharides with sulfate groups are human Tcell mitogens and murine polyclonal B-cell activators (PBAs). Cell Immunol 74:162-171

25. Carding SR, Hayday AC, Bootomly K 1992 Cytokines in T cell development. Immunol Today 4:171-176 